\title{
Pricing Strategies of Ambo Mineral Water from Producer and Sellers Perspectives'
}

\author{
Negash Geleta Etana \\ Department of Management \\ College of Business and Economics \\ Ambo University \\ West Shoa Zone Oromia Regional State, Ethiopia \\ E-mail: kenu2002@gmail.com
}

\begin{abstract}
The study was conducted on "Pricing strategies of Ambo Mineral Water from producers and sellers' perspectives" and a data was collected from sellers of Ambo Town West Shoa Zone Oromia Regional State. The main objective of the study is to see the pricing strategies of Ambo Mineral Water and the scope is delimited to sellers of Ambo Mineral Water found in Ambo Town. The sample size was determined based on the maturity strategies which more used when the responses of the respondents are redundant. Accordingly, the study is used sample size up to 54 to see the facts. To analyze the collected data the study used descriptive statistics for all parties of the study. The last section presents the conclusions and recommendations directed to the respondents. In conclusion, all the respondents have one or two pricing strategies and this implies that the respondents have more knowledge on the pricing strategies. Therefore, it is more essential to recommend all the respondents must have the right pricing strategies according to their offerings based on the customers' sensitivity.
\end{abstract}

Keywords: Pricing Strategies, Ambo Mineral Water, Producers, Sellers.

\section{Introduction}

In any business organization the objective is profit generation which obtained by marketing mix of price (revenue generator). Price is determined by considering cost structure; the extent to which the product is differentiated from competitors offering, the characteristics of consumers and the competition level is significant to the achievement of financial and competitive objectives of firms (Kotler and Armstrong, 200I). The business world begun to determine a common monetary value to the products they offer to the market called price. Price is the sum of all the values that consumers exchange for the benefits of having or using the product or service (Kotler, 2010). As different articles indicate, the price is also called rent (for an apartment), tuition (for education), fare (for travel), and interest (for borrowed money) (du Plessis \& Saayman, 20II). Price is one of the functions of marketing mix 4P's (McCarthy, 1960) that lonely produces revenues for growth and profitability of firms (Lovelock, 1996) not only this, but it can also be used as a communicator, as a bargaining tool and as a competitive weapon (Brassington and Pettit, 2003). Of all the decisions made by the marketing manager, pricing is undoubtedly the most visible tool from marketing mixes because it's direct impact on company performance in the market place and overall level of profitability. Price of Ambo Mineral Water is quite visible in nature as consumers know well what they are paying for the required product. Managers consider many factors in determining a pricing strategy. Of useful categorizes are intrinsic and extrinsic factors. Intrinsic factors are the baseline needs, such as costs, product characteristics, and soon, and the regulatory system which places limitations on how those needs can be met. Extrinsic factors are related to the economic and operating environment of procurement, including product differentiation, demand, and the number of firms involved. The business environment is getting much harder in competition to be a leader in the market place and this may be complex in case of setting the right price since it is challenging from time to time (Brennan, et al, 20II; Mastrobuoni et al., 20I4). This may be due to high competition, the availability of new low-cost manufacturing capacity, reductions in international trade barriers, and deregulation of many markets as well as the impact of Information technology. But in case of Ambo Mineral Water there is no competitors those share the market. But high cost would force it to set higher prices. According to some study from different sectors there is high research gap as pricing strategy is the most neglected element of the marketing mixes aside its significant contribution to the profitability and overall success of firms and also Ambo Mineral Water may share this default. Even though, the final goal of every company is profit making to ensure profitability in the long term to survival, and a larger attention is given to analysing different impacts influencing customer satisfaction. On the other hand; if price is not determined correctly, it could negatively impact on the products perceived quality and the company's profitability (Kotler, 20I0). Therefore, this study aims on evaluating the strategies, 
determinants of the price and setting the right price by showing how much cost, product quality and, demand affect price of Ambo Mineral Water.

\section{Objectives of the Study}

- To identify the pricing strategies used by Ambo Mineral Water.

- To see the knowledge level of pricing strategies of the sellers and producers of Ambo Mineral Water.

- To know factors and determinants of pricing strategies of Ambo Mineral Water.

\section{Significance of the Study}

Price sensitivity is higher in lower income society in which they prefer lower priced products than premium priced products. In this case market leader companies Ambo Mineral Water tried to apply various pricing strategies by rising and lowering of prices on breweries in order to create market demand. Therefore, this study is intended to evaluate pricing strategies dictating Ambo Mineral Water to set different prices for achievement of an optimum success while avoiding bad pricing strategies which is the most dangerous type of competition in the business world. Since price sensitivity is obvious in lower income society and economic inflation is accelerating the reduction of local currency value, the issue of price and pricing strategy is significant to Ambo Mineral Water manufacturer and marketing managers in Ethiopia to be benefited from results of this study by employing the outcome and create good insight on pricing strategies.

\section{Literature Review}

Anytime anything is sold, there must be a price involved. Pricing, is not primarily concerned with creating value. Rather, it could be said to be the marketing activity involved with capturing, or "harvesting," the value created by the other types of marketing activities. In the words of Philip Kotler, "Price is the marketing-mix element that produces revenue; the others produce costs." A price is what is given in a commercial exchange in return for a good or service. A price can have many names, such as "fee" or "rent" but should be not be confused with a company's "costs." Price is the amount of money that consumers pay for product or replace proprietary products that can affect the level of sales and profitability (Kotler, 2010).

Pricing Objectives: (I) Financial Objectives: The financial objectives are cost coverage, achievement of satisfactory profits, profit maximization, ROI (Return on Investment) and ROA (Return on Assets) Avlonitis \& Indounas (2004). (2) Competitive Objectives: This is a qualitative or non-financial objective of pricing whose main target is achieving competition related objectives through pricing strategies Avlonitis \& Indounas (2004). Sales quo objectives are tactical goals that encourage competition on factors other than price. Factors Affecting Pricing Strategies: (I) Internal/controllable factors: Internal factors are those found within the organization and could be seen for revision and controlling. These are; management decision, cost, othermarketing mixes, company objectives and product quality (Haron, 2016). (2) External/uncontrollable factors: Understanding these factors necessitates the marketer conduct research to monitor what is happening in each market the company serves since the consequence of these factors can vary by market (Haron, 2016).

Pricing Strategies: Market Based Pricing: The default method of pricing for many firms is using market prices. Many managers feel prices are dictated by the market and they have little or no control over them, Competitive Pricing: The distinction between competitive pricing and competition based on pricing should be made clear. Anderson et al. (2006) define competitive pricing as simply setting prices relative to what competitors are charging (Anderson et al., 2006) Cost-Based Pricing: Cost pricing or costplus pricing is the practice of adding some percentage to known costs to arrive at the offering price (Anderson et al., 2006) Value-Based Pricing: Value based pricing can be defined as setting a price in relation to an offering's value (Anderson et al., 2006) Price Skimming: When the goal is to capture as much of the customer perceived value as possible, "price skimming" might be the method of choice, target returns pricing: Target return pricing is often used interchangeably with cost-plus pricing. Brooks claims that the additional time and effort to produce a better price point may not be offset by the rise in precision, Penetration/Promotional Pricing: This form of pricing strategy, also known as promotional pricing, involves temporarily setting prices below the market price or even lower than cost price, Auction Pricing: The seller allows the buyers to compete for the product by asking them to quote the highest price they would like to pay for it, List pricing: Setting one price without differentiating it according to the different market segments that the company might target (Langeard, 2000), Differentiated pricing: Offering different prices to different customers on the basis of a number of criteria such as the time of the purchase, the place of the purchase or consumption of the service and the customers" personal characteristics (Islam, 2016; Lee and Ng, 200I), Negotiated pricing: Prices are determined on the basis of individual agreements between the company and its customers (Berry and Yadav, 1996), Cash discounts pricing: Discounts for those customers that pay their total amount within a predetermined time period (Langeard, 2000), Trade discounts pricing: Discounts to agents and distributors in order to promote and support the product or service (Ibid), Loss-leader pricing: A service is offered at a low price (even below cost) in order to 
attract customers that will be offered other more profitable and higher-priced services (Kurtz and Clow, I998), Image/ Prestige Pricing: Setting a high price in order to convey an exclusivity image (Naipaul and Parsa, 200I; Rao and Monroe, 1996).

\section{Method}

\section{I. Study Area}

The factory of Ambo Mineral Water found in West Shoa Zone Oromia Regional State specifically at Ambo (Senkele) which is far $130 \mathrm{~km}$ from Addis Ababa, capital city of Ethiopia. The data for this study collected from employees of the factory and sellers of the mineral water which found around ambo town.

\subsection{Population and Sample}

The population for the study were some selected staffs of the factory, sellers and in the Ambo Town. Sample size determined based on the saturation/ redundancy which means as the number of the sample size increase the variation of the information is decrease. In this case since more of the respondents replied the same response no need to increase the sample respondents. The respondents sampled randomly according to convenience for the study location.

\subsection{Data Sources, Instrument and Analysis}

For study primary was used which obtained from staffs sellers/distributors of the Mineral Water around Ambo Town. For data collection structured questionnaire was used and the collected data was analysed using SPSS V.23. The study used descriptive statistics (frequency distribution).

\section{Results}

\section{I. Respondent Profiles}

Table I. Respondent Profiles

\begin{tabular}{|c|c|c|c|}
\hline & Category & Frequency & Per cent \\
\hline \multirow[t]{4}{*}{ I. Age } & $20-30$ & 13 & 24 \\
\hline & $3 I-40$ & $2 \mathrm{I}$ & 39 \\
\hline & $>4 \mathrm{I}$ & 20 & 37 \\
\hline & Total & 54 & $\mathrm{IO0}$ \\
\hline \multirow[t]{3}{*}{ 2. Gender } & Male & 29 & 53.7 \\
\hline & Female & 25 & 46.3 \\
\hline & Total & 54 & 100.0 \\
\hline \multirow[t]{4}{*}{ 3. Education } & Grade 12 & 23 & 42.6 \\
\hline & Diploma/level & 26 & 48.1 \\
\hline & Degree and above & 5 & 9.3 \\
\hline & Total & 54 & 100.0 \\
\hline \multirow[t]{3}{*}{ 4. Education Specialization } & Natural & 36 & 66.7 \\
\hline & Social & 18 & 33.3 \\
\hline & Total & 54 & 100.0 \\
\hline \multirow[t]{3}{*}{ 5. Business Type } & Hotel & II & 20.4 \\
\hline & Grocery/retailer & 43 & 79.6 \\
\hline & Total & 54 & 100.0 \\
\hline \multirow[t]{4}{*}{ 6. Role/Responsibility } & Manager & 26 & 48.1 \\
\hline & Salesperson & II & 20.4 \\
\hline & Owner & 17 & 31.5 \\
\hline & Total & 54 & 100.0 \\
\hline
\end{tabular}

Source: Primary data, 2020

The above table presents six profiles of respondents. The average age of the respondents was I4\%, 37\% and 39\% respectively for the categories of the respondents. In case of education majority of the respondents were diploma holders which account about 48.I \% and for gender distribution majority of them were male which account about $53.7 \%$ from all respondents. More of the specializations of the respondents were natural science which accounts almost $66.7 \%$ as reported in the table above. As it can be seen also in the table, more of the business type was groceries which account about 79.6\%. Finally, according to the role/responsibility majority of the respondents were managers. 


\subsection{Awareness of Price as the Marketing Mix}

Table 2. Awareness of Price as the Marketing Mix

\begin{tabular}{|c|c|c|c|}
\hline & Category & Frequency & Per cent \\
\hline \multirow[t]{4}{*}{ I. Price affects the level of sales \& profitability } & Yes & 24 & 44.4 \\
\hline & No & II & 20.4 \\
\hline & I don't know & 19 & 35.2 \\
\hline & Total & 54 & 100.0 \\
\hline \multirow[t]{4}{*}{ 2. Price is the amount of money consumers pay } & Yes & 27 & 50.0 \\
\hline & No & II & 20.4 \\
\hline & I don't know & 16 & 29.6 \\
\hline & Total & 54 & 100.0 \\
\hline \multirow{4}{*}{ 3. Price produces revenue others produce costs. } & Yes & 32 & 59.3 \\
\hline & No & II & 20.4 \\
\hline & I don't know & II & 20.4 \\
\hline & Total & 54 & 100.0 \\
\hline \multirow[t]{4}{*}{ 4. Price is commercial exchange in return for goods. } & Yes & 25 & 46.3 \\
\hline & No & II & 20.4 \\
\hline & I don't know & 18 & 33.3 \\
\hline & Total & 54 & 100.0 \\
\hline \multirow[t]{4}{*}{ 5. Price is the action of harvesting value. } & Yes & 24 & 44.4 \\
\hline & No & II & 20.4 \\
\hline & I don't know & 19 & 35.2 \\
\hline & Total & 54 & 100.0 \\
\hline
\end{tabular}

Source: Primary data, 2020

As it is shown in the table on the awareness of pricing in relating to the business concept more respondents have no knowledge what price and its role for profit generation. In the first item "the price affects the level of sales $\&$ profitability's" majority of the respondents replied as they have information which account about $44.4 \%$ and next about $35.2 \%$ have no information about the concept of price as the marketing mix elements. In general, as presented in the table all the respondents simple responded for the question provided but in detail, they have no any information about the price and its role for the business. As it can be observed from the table all the respondents replied more values for yes options next, I don't know. Then this result shows us as more the respondent has no information about the price as it is ingredients of marketing strategies. Then in general this result shows us as the respondent missed one prominent element for their success.

\subsection{Price Determinants}

Table 3. Price Determinants

\begin{tabular}{lccc}
\hline & Category & Frequency & Per cent \\
\hline \multirow{3}{*}{ Price Determinants } & Producer & $\mathrm{I}$ & 29.6 \\
\cline { 2 - 4 } & Owner & 9 & $\mathrm{I} 6.7$ \\
\cline { 2 - 4 } & Manager/seller & $\mathrm{I}$ & 29.6 \\
\cline { 2 - 4 } & Customer & 3 & 5.6 \\
\cline { 2 - 4 } & & $\mathrm{I}$ & $\mathrm{I} 8.5$ \\
\cline { 2 - 4 } & & 54 & $\mathrm{I} 00.0$ \\
\hline
\end{tabular}

Source: Primary data, 2020

According to the above result more the price is determined by producers and a manager which is account about $29.6 \%$. But the value given for the customers is less but the profit of the company totally comes from customers and the customers are more price sensitive in the market place. According to some literature in a small business organization, the owner/manager heavily involved in, and most responsible for, pricing activities and in a large organization, many people within the organization play a role in pricing setting activities. In many large organizations, product manager has much responsibility for setting prices. So as the result shows the price decision participants are more appropriate to set up the right price to increase profit of the organization. 
6.4 Objectives of Pricing

Table 4. Objectives of Pricing

\begin{tabular}{|c|c|c|c|}
\hline & Category & Frequency & Per cent \\
\hline \multirow[t]{4}{*}{ Pricing Objectives } & Competitive Objective & I9 & 35.2 \\
\hline & Financial Objective & II & 20.4 \\
\hline & Both & 24 & 44.4 \\
\hline & Total & 54 & 100.0 \\
\hline
\end{tabular}

Source: Primary data, 2020

As presented in the above table more the respondents replied for both objectives which account about $44.4 \%$. This result shows the pricing objectives are flexible the over the time. According to some previous studies this may be due to environmental or organizational conditions (Shipley and Jobber, 200I). The financial objectives more covers profit maximization return on Investment) and return on assets (Avlonitis \& Indounas, 2004). In general, this result shows as the decision makers have no more insights on the objectives of the pricing.

\subsection{Pricing Strategies}

Table 5. Pricing Strategies

I. Auction pricing

I. Auction pricing

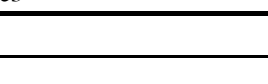

\begin{tabular}{cr} 
Category & Frequen \\
Always Used & 10 \\
\hline Sometimes used & 7 \\
\hline Not used at all & 37 \\
\hline Total & 54
\end{tabular}

2. Discounts pricing

Always Used 12

Sometimes used 5

\begin{tabular}{ccc}
\hline Not used at all & 37 & 68.5 \\
\hline Total & 54 & 100.0 \\
\hline Always Used & 8 & 14.8 \\
\hline Sometimes used & 7 & 13.0 \\
\hline Not used at all & 39 & 72.2 \\
\hline Total & 54 & 100.0
\end{tabular}

3. Competitive pricing

\section{Cost-plus pricing}

\begin{tabular}{c} 
Always Used \\
\hline Sometimes used \\
\hline Not used at all \\
\hline Total
\end{tabular}

\section{Customized prices}

Always Used

24

44.4

7

23

54

\begin{tabular}{c}
\hline Sometimes used \\
\hline Not used at all \\
\hline Total
\end{tabular}

6. Differentiated pricing

\begin{tabular}{ccc}
\hline Total & 54 & 100.0 \\
\hline Always Used & 13 & 24.1 \\
\hline Sometimes used & 9 & 16.7 \\
\hline Not used at all & 32 & 59.3 \\
\hline Total & 54 & 100.0 \\
\hline Always Used & 16 & 29.6 \\
\hline Sometimes used & 9 & 16.7 \\
\hline Not used at all & 29 & 53.7 \\
\hline Total & 54 & 100.0 \\
\hline
\end{tabular}

Source: Primary data, 2020

As it can be observed from the above table except on cost-plus pricing the respondents have no more information since they cannot sell below the purchasing / production costs. In general, the above result shows almost all the respondents replied for as they are not used more pricing strategies for their strategies of ambo mineral water. According to Monroe (2003), price decisions/strategies are one of the most important decisions of management because it affects profitability and the companies' return along with their market competitiveness. Thus, even though the task of developing and defining prices is complex and 
challenging, managers must involve process of how customers perceive prices, and how to develop the perceived value, what are the intrinsic and relevant costs to comply with this necessity, as well as consider the pricing objectives of the company and their competitive position in the market place. In this way, Nagle and Hogan (2007) argue that companies which do not manage their prices lose control over them, impairing their profitability and cost effectiveness mainly due to the customers will on paying a determinate price, which not only does it depend on the perceived value, but also depends on the prices set by the leading competitors.

Table 6. Pricing Strategies

\begin{tabular}{|c|c|c|c|}
\hline & Category & Frequency & Percept \\
\hline \multirow[t]{4}{*}{ 8. Image/ prestige pricing } & Always Used & 16 & 29.6 \\
\hline & Sometimes used & 9 & I6.7 \\
\hline & Not used at all & 29 & 53.7 \\
\hline & Total & 54 & I00.0 \\
\hline \multirow{4}{*}{ 9. List pricing } & Always Used & 16 & 29.6 \\
\hline & Sometimes used & I0 & 18.5 \\
\hline & Not used at all & 28 & 51.9 \\
\hline & Total & 54 & I00.0 \\
\hline \multirow[t]{4}{*}{ 10. Loss-leader pricing } & Always Used & 17 & 31.5 \\
\hline & Sometimes used & 9 & 16.7 \\
\hline & Not used at all & 28 & 51.9 \\
\hline & Total & 54 & 100.0 \\
\hline \multirow[t]{4}{*}{ 11. Time pricing } & Always Used & 17 & 31.5 \\
\hline & Sometimes used & II & 20.4 \\
\hline & Not used at all & 26 & 48.1 \\
\hline & Total & 54 & 100.0 \\
\hline \multirow[t]{4}{*}{ 12. Negotiated pricing } & Always Used & 16 & 29.6 \\
\hline & Sometimes used & II & 20.4 \\
\hline & Not used at all & 27 & 50.0 \\
\hline & Total & 54 & 100.0 \\
\hline \multirow{4}{*}{$\begin{array}{l}\text { 13. Penetration pricing(low } \\
\text { price) }\end{array}$} & Always Used & I3 & $24 . \mathrm{I}$ \\
\hline & Sometimes used & II & 20.4 \\
\hline & Not used at all & 30 & 55.6 \\
\hline & Total & 54 & 100.0 \\
\hline
\end{tabular}

The above table presents six pricing strategies. Also, on the in table almost all the respondents have no more information to price Ambo Mineral Water to achieve their objectives. As some respondents replied image pricing sometimes may be used when the Hotels are standard and more decorate to add value to customers as place pricing based on the profession of the customer in the segmented marketing. Penetration pricing (low price) is also sometimes may be used when the sellers open a new business to attract a new customer in this case the price of the Ambo mineral water may be low up to I2 Ethiopian birrs. This form of pricing strategy, also known as promotional pricing, involves temporarily setting prices below the market price or even lower than cost price. This is often used to maximize rapid market entry into new markets or the market entry of new products into existing markets. Also, as information is provided in the above table negotiated pricing are determined on the basis of individual agreements between the company and its customers.

Table 7. Pricing Strategies

\begin{tabular}{lccc}
\hline & Category & Frequency & Per cent \\
\hline I5. Price skimming(high price) & Always Used & I6 & 29.6 \\
\cline { 2 - 4 } & Sometimes used & 8 & 14.8 \\
\cline { 2 - 4 } & Not used at all & 30 & 55.6 \\
\cline { 2 - 4 } & Total & 54 & 100.0 \\
\hline I6. Promotional pricing & Always Used & I4 & I3.0 \\
\cline { 2 - 4 } & Sometimes used & 7 & 61.I \\
\cline { 2 - 4 } & Not used at all & 33 & \\
\hline
\end{tabular}




\begin{tabular}{|c|c|c|c|}
\hline & Total & 54 & 100.0 \\
\hline \multirow{4}{*}{ I7. Place Pricing } & Always Used & $\mathrm{I} 4$ & 25.9 \\
\hline & Sometimes used & IO & 18.5 \\
\hline & Not used at all & 30 & 55.6 \\
\hline & Total & 54 & I00.0 \\
\hline \multirow[t]{4}{*}{ I8. Relationship pricing } & Always Used & 15 & 27.8 \\
\hline & Sometimes used & 9 & 16.7 \\
\hline & Not used at all & 30 & 55.6 \\
\hline & Total & 54 & 100.0 \\
\hline \multirow[t]{4}{*}{ 19. Target returns pricing } & Always Used & 15 & 27.8 \\
\hline & Sometimes used & 9 & 16.7 \\
\hline & Not used at all & 30 & 55.6 \\
\hline & Total & 54 & 100.0 \\
\hline \multirow[t]{4}{*}{ 20. Value-based pricing } & Always Used & 17 & 31.5 \\
\hline & Sometimes used & 9 & I6.7 \\
\hline & Not used at all & 28 & 51.9 \\
\hline & Total & 54 & 100.0 \\
\hline
\end{tabular}

Source: Primary data, 2020

The above table also presents pricing strategies such as price skimming (high price), seasonal pricing, promotional pricing, place pricing, psychological pricing, relationship pricing, target returns pricing and value-based pricing to see the practically if these strategies used by Ambo Mineral Water Factory. As presented in the table above skim pricing is sometimes may be used but in general the respondents have more information how to set up the price for the products they are selling for instance more the respondents replied as they are not used at all which account about $55.6 \%$ from the given options. As some evidence skimming pricing strategy is used to maximize profits by maintaining the highest price possible of new products that face a high demand from specific market segments.

\subsection{Factors Affecting Pricing Strategies}

Table 8. Pricing Strategies

\begin{tabular}{lccc}
\hline & Category & Frequency & Percept \\
\hline \multirow{3}{*}{ Factors affecting Pricing strategies } & Internal & 5 & 9.3 \\
\cline { 2 - 4 } & External & 10 & 18.5 \\
\cline { 2 - 4 } & Both & 39 & 72.2 \\
\cline { 2 - 4 } & Total & 54 & 100.0 \\
\hline
\end{tabular}

Source: Primary data, 2020

As presented in the above table there are external and internal factors which affect pricing decisions of the company. According to the results in the above table more the respondents replied as the presence of both external and internal factors in pricing strategies which can affect Ambo Mineral Water Factory which account about $72.2 \%$. In case of internal/controllable factors marketing decisions are directed by the overall objectives of the company. Internal factors are those found within the organization and could be seen for revision and controlling. These are management decision, cost, othermarketing mixes, company objectives and product quality (Haron, 2016). Also, in case of external/uncontrollable factors there are a number of factors, which are not controlled by the company that influence pricing objectives. Understanding these factors necessitates the marketer conduct research to monitor what is happening in each market the company serves since the consequence of these factors can vary by market (Haron, 2016).

\section{Conclusion}

The study was found some facts of pricing strategies following by Ambo Mineral Water from the perspectives of the respondents. Accordingly, many sellers focus on different pricing strategies but all the respondents have no more detail concepts on the pricing strategies. The more strategies the respondent support is cost-plus pricing since they cannot sell below the production cost. As the study shows the object of the sellers more focuses on the financial objective to increase their profitability. The study also tried to see the factors affecting pricing strategies focusing on the internal and externals. In this case as the respondents replied the pricing strategies both affected by externals and internals. Therefore, in general based on the study it can be concluded that both the sellers and producer have no clear pricing strategies on ambo mineral water. 


\section{Recommendation}

The producer and sellers are required to give higher attention to the pricing strategies to capture more values/revenues. They are also to give higher consideration to factors affecting pricing strategies. Accordingly, it is better for future researches to conduct on the same titled research on in this factory by adding different variables. As indicated in the result the respondents have no more insight on the pricing strategies then the producer/owners and sellers must create the awareness of pricing strategies.

\section{Acknowledgement}

I would like to express my special thanks of gratitude to the participants for the completion of this paper as well as my university department who gave me the golden support to do complete this wonderful project which helped me to know about new things. Secondly, I would also like to thank my parents and friends who helped me a lot in finalizing this project within the limited time frame.

\section{References}

Anderson, J. C., Narus, J. A., \& Van Rossum, W. (2006). Customer value propositions in business markets. Harvard business review, 84(3), 90.

Avlonitis, G. J., \& Indounas, K. A. (2004). The impact of market structure on pricing objectives of service firms. Journal of Product \& Brand Management.

Brassington, F. \& Pettitt, S. (2003). Principles of Marketing, 3rd ed., Pearson Education, Harlow.

Brennan, R., Canning, L., \& McDowell, R. (201 I). Analyzing facts on pricing decisions.

Berry, L. L., \& Yadav, M. S. (1996). Capture and communicate value in the pricing of services. MIT Sloan Management Review, 37(4), 4I.

du Plessis, E., \& Saayman, M. (20II). Factors influencing pricing in the accommodation sector in South Africa. The Southern African Journal of Entrepreneurship and Small Business Management, 4(I), 24-47.

Haron, A. J. (2016). Factors influencing pricing decisions. International Journal of Economics \& Management Sciences, 5(I), I -4 .

Islam, K. M. A. (2016). Factors influencing consumers purchase decision: a case study of Pantene shampoo. Indian Journal of Science, 23(88), 910-923. Retrieved from https://discoveryjournals.org/science/current_issue/2016/A74.pdf

Kotler, P. (2010). Marketing: An introduction. I0th ed. New Jersey, Prentice Hall.

Kotler, P., \& Armstrong, G. (200I). Principles of marketing: Activebook I.0. Upper Saddle River, NJ: Prentice hall.

Kurtz, D.L., \& Clow, K.E. (I998). Services Marketing, John Wiley \& Sons, New York, NY.

Langeard, E. (2000, June). Specificity of the pricing policy in service activities. In Innovations Perspect. Internat. Res. Seminar in Service Management, La Londe Les Maures, France (pp. 243-256).

Lee, K. S., \& Ng, I. C. (200I). Advanced sale of service capacities: A theoretical analysis of the impact of price sensitivity on pricing and capacity allocations. Journal of Business Research, 54(3), 219-225.

Lovelock, C. H., \& Lovelock, C. H. (1996). Services marketing (p. 29). Upper Saddle River, NJ: Prentice Hall.

Mastrobuoni, G., Peracchi, F., \& Tetenov, A. (2014). Price as a signal of product quality: Some experimental evidence. Journal of Wine Economics, $9(2)$, I35-I52.

McCarthy. (1960). Principles of Services Marketing, McGraw- Hill, London.

Monroe, J. C. (2003). The dynamics of state formation: The archaeology and ethnohistory of pre-colonial Dahomey. University of California, Los Angeles.

Nagle, T., \& Hogan, J. (2007). Is your sales force a barrier to more profitable pricing... or is it you?. Business Strategy Series.

Naipaul, S., \& Parsa, H. G. (200I). Menu price endings that communicate value and quality. Cornell Hotel and Restaurant Administration Quarterly, 42(I), 26-37.

Rao, A. R., \& Monroe, K. B. (I996). Causes and consequences of price premiums. Journal of Business, 69(4), 5 I I-535.

Shipley, D., \& Jobber, D. (200I). Integrative pricing via the pricing wheel. Industrial Marketing Management, $30(3), 30$ I-3 I4.

\section{Copyrights}

Copyright for this article is retained by the author(s), with first publication rights granted to the journal. This is an open-access article distributed under the terms and conditions of the Creative Commons Attribution license (http://creativecommons.org/licenses/by/4.0/). 